\title{
Konfirmasi Toleransi Galur-galur Padi terhadap Cekaman Kekeringan secara Molekuler
}

\author{
Molecular Confirmation of Tolerance of Rice Lines to Drought Stress
}

\author{
Rina Hapsari Wening ${ }^{1}$, Willy Bayuardi Suwarno ${ }^{2}$, Bambang Sapta Purwoko ${ }^{2 *}$, \\ Indrastuti Apri Rumanti ${ }^{1}$, dan Amy Estiati ${ }^{3}$
}

\author{
${ }^{1}$ Balai Besar Penelitian Tanaman Padi, Jl. Raya 9, Sukamandi, Subang 41256, Jawa Barat, Indonesia \\ ${ }^{2}$ Departemen Agronomi dan Hortikultura, Fakultas Pertanian, Institut Pertanian Bogor \\ (IPB University), Jl. Meranti, Kampus IPB Darmaga, Bogor 16680, Indonesia \\ ${ }^{3}$ Lembaga Ilmu Pengetahuan Indonesia, Jl. Raya Jakarta-Bogor No. Km 46, Cibinong, Bogor 16911, Indonesia
}

Diterima 19 Juli 2021/Disetujui 24 Agustus 2021

\begin{abstract}
Phenotypic selection, especially for abiotic stresses, is often challenging. Molecular selection activities are needed to identify at the molecular level that a tolerant trait is genotypically proven. This study aimed at confirming the drought tolerance of rice lines using SSR markers RM164, RM228, RM248, dan RM328. The study was conducted at the LIPI Biotechnology Laboratory at Cibinong, Bogor, Indonesia from November to December 2017, using the polymerase chain reaction (PCR) technique. The results showed that the RM228 marker was associated with the character of leaf rolling scores, panicle length, number of tillers, number of filled grains per panicle, and productivity. This marker is therefore potential to be used for drought tolerance selection. Seven of the ten lines that indicated as tolerant at generative phase drought stress based on artificial screening, were confirmed molecularly, which were in the same group with the tolerant check 'Limboto'. The seven lines were B13983E-KA-12-2, B13507E-MR-19, B14366E-KY-50, BP20452e-PWK-0-SKI-1-1, BP20452e-PWK0-SKI-2-4, BP20452e-PWK-0-SKI-3-3, and BP29790d-PWK-3-SKI-1-5.
\end{abstract}

Keywords: drought tolerant, marker, polymerase chain reaction

\section{ABSTRAK}

Seleksi secara fenotipik, terutama terhadap cekaman abiotik, seringkali sulit dilakukan. Kegiatan seleksi secara molekuler diperlukan untuk mengidentifikasi hingga taraf molekuler bahwa suatu sifat toleran terbukti secara genotipik. Tujuan dari penelitian ini ialah untuk mengkonfirmasi sifat toleransi kekeringan galur-galur padi secara molekuler menggunakan marka SSR RM164, RM228, RM248, dan RM328. Penelitian dilaksanakan di Laboratorium Bioteknologi LIPI, Cibinong pada bulan November hingga Desember 2017, menggunakan teknik polymerase chain reaction (PCR). Hasil penelitian menunjukkan bahwa marka RM228 terkait dengan karakter skor menggulung, panjang malai, tinggi tanaman dan umur berbunga, sedangkan RM328 terkait dengan panjang malai, jumlah anakan, jumlah gabah isi per malai, dan produktivitas. Marka tersebut diduga dapat digunakan untuk seleksi toleransi kekeringan. Tujuh dari sepuluh galur yang terindikasi toleran terhadap cekaman kekeringan fase generatif berdasarkan skrining secara artifisial terkonfirmasi secara molekuler berada dalam satu kelompok dengan varietas pembanding toleran 'Limboto'. Ketujuh galur tersebut ialah B13983E-KA-12-2, B13507E-MR-19, B14366E-KY-50, BP20452e-PWK-0-SKI-1-1, BP20452e-PWK-0-SKI-2-4, BP20452ePWK-0-SKI-3-3, dan BP29790d-PWK-3-SKI-1-5.

Kata kunci: marka, toleransi kekeringan, polymerase chain reaction

\section{PENDAHULUAN}

Kegiatan seleksi merupakan salah satu proses penting dalam rangkaian program pemuliaan tanaman. Banyak peneliti yang mengkaji efisiensi seleksi dalam program pemuliaan tanaman seperti Yullianida et al. (2014) dan

\footnotetext{
* Penulis untuk korespondensi. e-mail: bspurwoko@apps.ipb. ac.id
}

Akbar et al. (2018). Seleksi secara fenotipik, terutama terhadap cekaman abiotik, seringkali sulit dilakukan. Hal tersebut salah satunya dikarenakan sulitnya mengkondisikan lingkungan homogen seperti yang dikehendaki. Cekaman kekeringan merupakan salah satu cekaman abiotik yang sulit untuk diterapkan pada saat melakukan skrining atau seleksi genotipe padi. Kesulitan melakukan seleksi terhadap cekaman kekeringan secara fenotipik adalah kehomogenan media dan tingkat cekaman kekeringan terjadi pada waktu 
yang tidak sesuai dengan perlakuan (Afa et al., 2013). Akbar et al. (2018) melaporkan bahwa belum ada teknik penapisan yang efektif memilah antara galur yang toleran dan peka terhadap cekaman kekeringan. Penelitian yang telah banyak dilakukan ialah skrining genotipe padi terhadap cekaman kekeringan fase vegetatif seperti yang telah dilakukan oleh Widyastuti et al. (2016), Cahyadi et al. (2013), dan Kartina et al. (2019).

Banyakstudiyangmelaporkanbahwaterdapatbeberapa karakter yang dapat dijadikan sebagai karakter seleksi seperti panjang akar seminal, bobot kering akar seminal, persentase perkecambahan (Akbar et al., 2018), panjang akar, bobot kering akar dan bobot kering kecambah untuk skrining toleransi kekeringan pada fase bibit (Afa et al., 2013). Hasil penelitian Wening et al. (2019) diperoleh informasi bahwa berdasarkan seleksi secara fenotipik dengan menggunakan karakter skor mengering, menggulung dan produktivitas, telah didapatkan 10 galur yang toleran terhadap cekaman kekeringan dari 99 galur yang diuji. Meskipun skrining kekeringan secara fenotipik sudah banyak dilakukan, studi pengembangan marka molekuler untuk penapisan toleransi kekeringan pada padi perlu dilakukan.

Marka DNA dapat dimanfaatkan sebagai alat bantu seleksi. Kegiatan seleksi secara molekuler diperlukan untuk mengidentifikasi bahwa suatu sifat toleran terbukti secara genotipik. Banyak peneliti yang menggunakan marka DNA sebagai sarana dalam melakukan seleksi. Nuraida (2012) menyatakan bahwa marker assisted selection (MAS) lebih efisien dibandingkan seleksi secara fenotipik. Kegiatan seleksi dengan menggunakan MAS akan lebih efektif dan efisien karena hanya didasarkan pada sifat genetik tanaman dan tidak dipengaruhi oleh faktor lingkungan. Kegiatan pemuliaan tanaman dapat menjadi lebih cepat dan tepat jika memanfaatkan marka molekuler. Beberapa peneliti telah menggunakan MAS dalam melakukan seleksi, seperti Tresniawati et al. (2014) yang menggunakan teknik MAS untuk menyeleksi kakao berkadar lemak tinggi.

Marka molekuler yang paling banyak dimanfaatkan pada penelitian tanaman pangan ialah marka simple sequence repeats (SSR). SSR merupakan marka dari reaksi rantai polimerase (polymerase chain reaction, $\mathrm{PCR}$ ) yang menggunakan sekuen-sekuen nukleotida sebagai primer. Penggunaan marka SSR didasarkan beberapa pertimbangan, diantaranya adalah primer terdistribusi secara melimpah dan merata dalam genom serta variabilitasnya tinggi, memiliki reprodusibilitas yang tinggi, dapat digunakan sebagai studi keragaman genetik (Yang et al., 2011), serta mampu mendeteksi homosigositas dan kemurnian genetik inbrida secara akurat (Daniel et al., 2012; Hipi et al., 2012; Semagn et al., 2012; Mulsanti et al., 2013). Kelemahan teknik ini ialah marka SSR belum tersedia pada semua spesies tanaman, sehingga untuk merancang primer baru memerlukan waktu yang lama dan biaya yang mahal (Bahagiawati, 2011). Namun demikian, untuk tanaman padi telah ditemukan banyak marka SSR yang sesuai untuk kegiatan skrining atau seleksi sifat tertentu.

Seleksi secara genotipik menggunakan marka SSR terkait dengan toleransi terhadap kekeringan telah banyak dilakukan. Efendi et al. (2014) menggunakan marka SSR untuk menyeleksi jagung inbrida toleran terhadap kekeringan. Hasil penelitian Zhao et al. (2008) menyebutkan bahwa marka SSR RM258 dan RM228 yang terletak pada kromosom 10 berhubungan dengan karakter laju fotosintesis, frekuensi stomata daun, bobot daun spesifik, dan hasil, dimana seluruh karakter tersebut berkaitan dengan toleransi terhadap kekeringan. Menurut Lang dan Buu (2008), RM328 berada di kromosom 9 dan diduga terkait erat dengan toleransi kekeringan. Selvi et al. (2015) menyebutkan bahwa RM248 pada kromosom 7 terkait dengan pertumbuhan akar.

Penelitian ini bertujuan untuk mengkonfirmasi toleransi kekeringan secara molekuler menggunakan marka SSR RM164, RM228, RM248, dan RM328. Hasil penelitian ini digunakan untuk mendukung hasil penelitian skrining galur-galur padi terhadap cekaman kekeringan secara fenotipik (Wening et al., 2019).

\section{BAHAN DAN METODE}

Metode skrining toleransi kekeringan secara molekuler menggunakan marka SSR yang terkait dengan toleransi terhadap kekeringan. Marka SSR terkait toleransi terhadap kekeringan yang digunakan ialah RM164, RM228, RM248, dan RM328 (Zao et al., 2008; Yue et al., 2006; Lang dan Buu, 2008). Materi yang digunakan sebanyak 96 genotipe padi yang terdiri atas 92 galur padi dan varietas pembanding yaitu Inpari 30, IR42, Limboto sebagai varietas pembanding untuk sifat toleran kekeringan, dan IR20 sebagai varietas pembanding untuk sifat peka terhadap kekeringan (Lampiran 1). Isolasi DNA dilakukan menggunakan metode cetyl trimethylammonium bromide (CTAB) dengan sampel daun tanaman. Program reaksi polymerase chain reaction (PCR) yang digunakan ialah preheat lid $105^{\circ} \mathrm{C}$, initial denaturation $95{ }^{\circ} \mathrm{C}$ selama 2 menit, 35 kali siklus denaturation 95 ${ }^{\circ} \mathrm{C}$ selama 30 detik, annealing $55{ }^{\circ} \mathrm{C}$ (tergantung ratarata dari temperate melting primer reverse dan forward) selama 45 detik, dan extension $72{ }^{\circ} \mathrm{C}$ selama 45 detik, selanjutnya final extension pada $72{ }^{\circ} \mathrm{C}$ selama lima menit. Produk PCR disimpan dalam suhu $4{ }^{\circ} \mathrm{C}$ sampai digunakan untuk elektroforesis. Produk PCR dielektroforesis pada gel agarose dengan daya 100 volt selama 1-2 jam sesuai dengan ukuran fragmen DNA dalam buffer Tris-borateEDTA (TBE) 10X dengan konsentrasi 18.93\%. Loading dye diberikan sebagai pemberat dan penanda pergerakan DNA. $\mathrm{Kb}$ Ladder disertakan untuk mengetahui ukuran fragmen DNA. Pewarnaan produk elektroforesis dilakukan dengan cyber safe atau ethidium bromide dan visualisasinya dilihat menggunakan Geldoc/UV transilluminator.

Data molekuler diperoleh dalam bentuk pita-pita DNA hasil amplifikasi dengan ukuran tertentu dari tiap genotipe yang diuji. Pengkelasan hasil analisis molekuler menggunakan perangkat lunak PBSTAT-CL (www.pbstat. com) menggunakan metode dissimilarity Gower dan pengkelasan yaitu average linkage. PBSTAT merupakan perangkat lunak yang mudah digunakan. Sitaresmi et al. (2019) menggunakan PBSTAT untuk menganalisa interaksi genotipe dengan lingkungan pada tanaman padi. Pada penelitian ini dilakukan pula uji $\mathrm{t}$ data molekuler 
dianalisis menggunakan Minitab. Uji t digunakan untuk membandingkan rata-rata nilai fenotipe dari kelompok genotipe dengan skor marka molekuler 0 (tanpa pita) dibandingkan dengan kelompok genotipe dengan skor 1 (ada pita) dan membandingkan antar kelompok hasil analisis gerombol.

\section{HASIL DAN PEMBAHASAN}

\section{Hasil Visualisasi Marka SSR Terkait Toleransi Kekeringan}

Toleransi maupun adaptasi padi terhadap kekeringan merupakan sifat yang dikendalikan oleh banyak gen (polygenes) (Lang dan Buu, 2008). Hal tersebut menandakan bahwa evaluasi fenotipik galur-galur padi untuk memperoleh galur yang toleran terhadap cekaman kekeringan sulit untuk dilakukan. Hal tersebut mendasari dilakukannya konfirmasi toleransi kekeringan melalui studi molekuler menggunakan marka SSR. Penggunaan marka SSR dilakukan karena marka molekuler ini paling banyak digunakan pada tanaman pangan, dan pada tanaman padi telah banyak ditemukan marka SSR yang sesuai. Seleksi secara genotipik menggunakan marka SSR terkait dengan toleransi kekeringan telah banyak dilakukan (Efendi et al., 2014; Zhao et al., 2008; Lang dan Buu, 2008).

Empat marka molekuler SSR yang digunakan, yaitu marka RM164, RM 228, RM248, dan RM328 yang pada percobaan sebelumnya menunjukkan sifat polimorfis. Hasil analisis visual menunjukkan bahwa pada marka RM164 tidak diperoleh hasil visualisasi yang baik, sedangkan ketiga marka lainnya menunjukkan visualisasi yang baik dan polimorfis terhadap 2-4 varietas pembanding yang digunakan. Varietas pembanding tersebut adalah A. Inpari 30, B. IR42, C. Limboto dan D. IR20. Selanjutnya seluruh genotipe uji, dievaluasi DNA nya menggunakan 3 marka yaitu RM 228, RM248, RM328, data hasil visualisasinya dapat dilihat pada Gambar 1-3.

Marka RM228 bersifat polimorfis terhadap pembanding peka dan toleran kekeringan. Limboto (pembanding toleran) teramplifikasi pada sekitar $100 \mathrm{bp}$, sedangkan IR20 (pembanding peka) teramplifikasi di 150 bp. Gambar 1 menunjukkan visualisasi DNA galur-galur yang diuji dengan RM 228. Marka ini dilaporkan terpaut erat dengan sifat menggulung daun (leaf rolling) sebagai salah satu penciri toleransi terhadap kekeringan dan pada kromosom 10 (Anupam et al., 2017). Marka SSR RM248 diketahui berada pada kromosom 7 dan terpaut dengan karakter perkembangan akar (root development) terutama terkait dengan volume akar yang terekpresi baik pada kondisi optimum maupun terinduksi cekaman kekeringan (Yue et al., 2006). Hasil visualisasi pita DNA dengan marka RM 248 ditunjukkan pada Gambar 2.

Visualisasi pita DNA dengan marka RM328 pada galur-galur yang diamati dapat dilihat pada Gambar 3 .

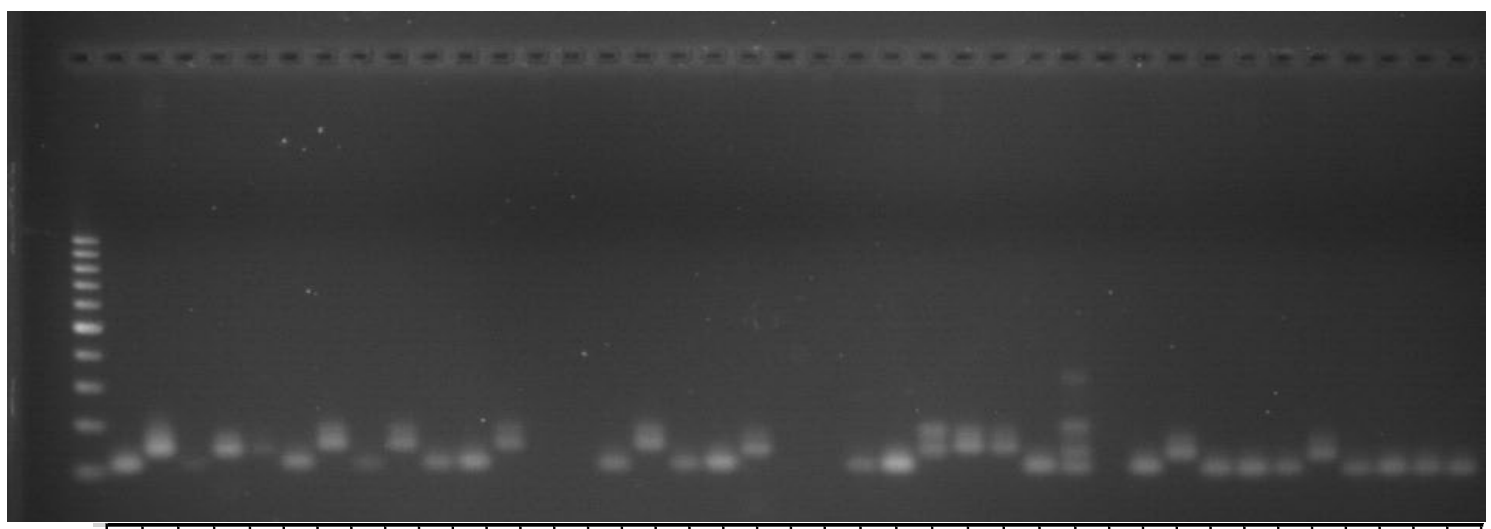

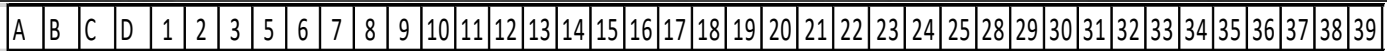

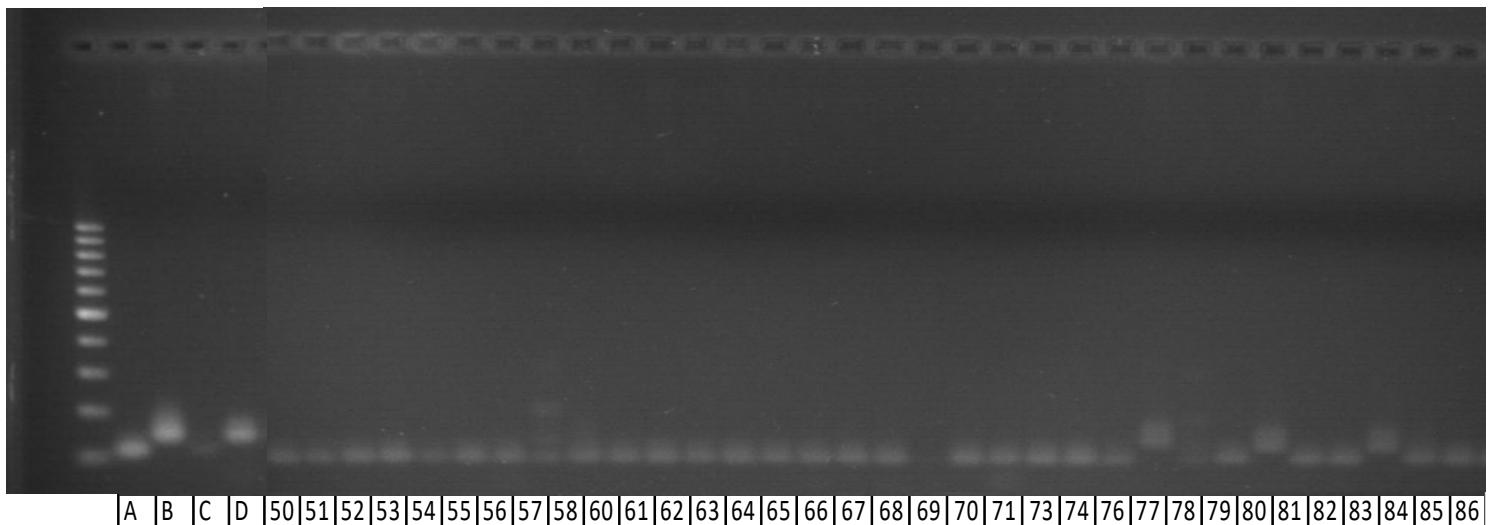

Keterangan: A = Inpari 30 Ciherang Sub1; B = IR42; C = Limboto; D = IR20; Angka 1, 2, 3, dan seterusnya menyatakan nomor galur; Ladder $1,000 \mathrm{bp}$

Gambar 1. Visualisasi RM228 pada analisis molekuler galur-galur padi 

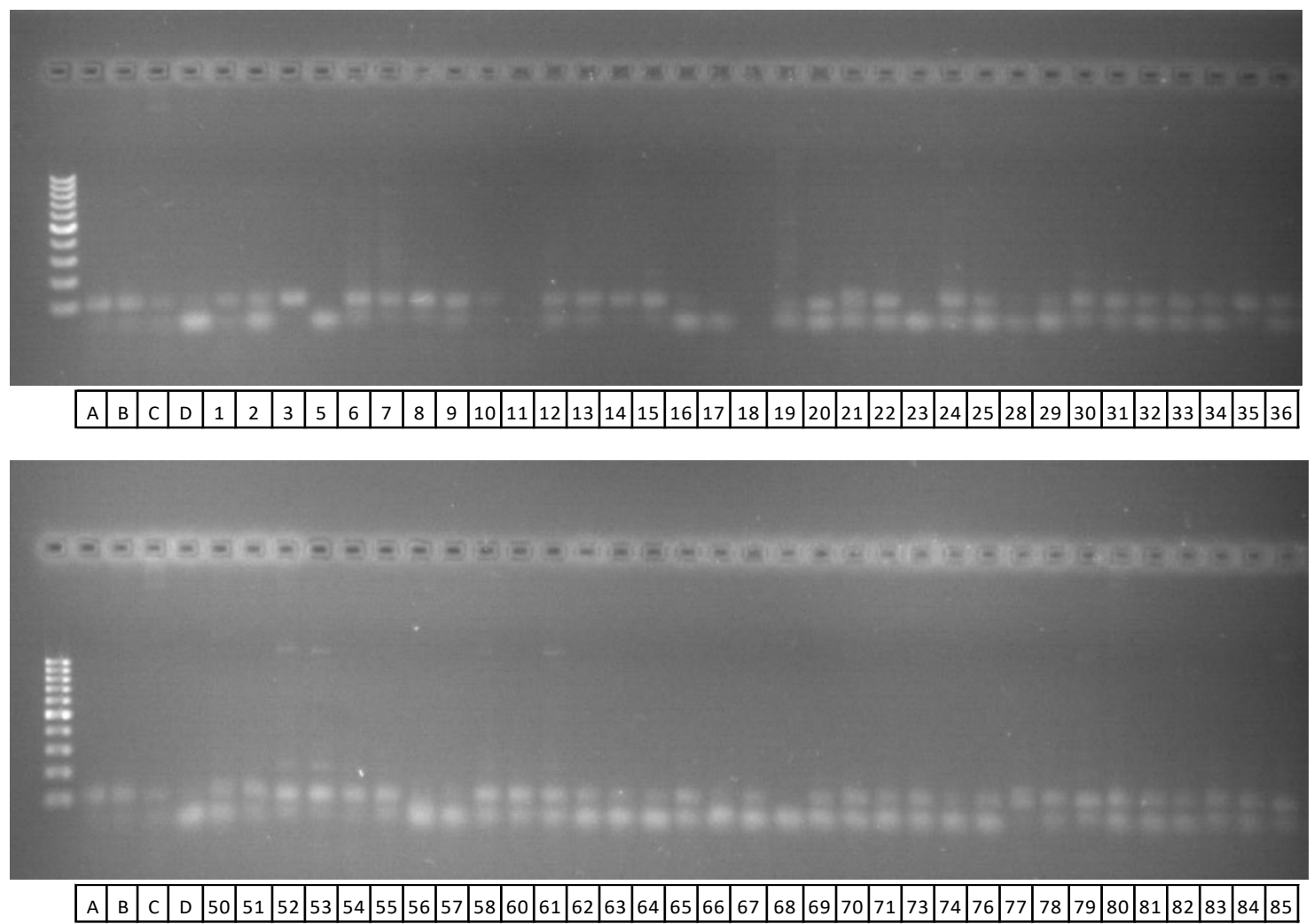

Keterangan: A = Inpari 30 Ciherang Sub1; B = IR42; C = Limboto; D = IR20; Angka 1, 2, 3, dan seterusnya menyatakan nomor galur; Ladder $1,000 \mathrm{bp}$

Gambar 2. Visualisasi RM248 pada analisis molekuler galur-galur padi

Hasil amplifikasi pada marka RM328 tersebut terlihat adanya fragmen smear. Fragmen smear muncul sebagai akibat terpotongnya untaian DNA penyusun kromosom pada saat proses isolasi DNA. Hal tersebut dapat disebabkan kerusakan mekanis akibat aktivitas enzim RNAse pada saat rangkaian isolasi DNA. Pita DNA antar sampel yang terlihat pada gel agarosa menunjukkan intensitas dan konsentrasi DNA tiap sampel. Tinggi rendahnya konsentrasi DNA dapat dipengaruhi oleh senyawa yang terdapat pada tiap sampel, prosedur ekstraksi dan isolasi DNA, serta metode presipitasi DNA.

\section{Klasterisasi Genotipe Padi Berdasarkan Marka Molekuler}

Tiap hasil amplifikasi dari tiap marka diskoring menjadi data biner per lokus. Selanjutnya berdasarkan data skoring marka dibuat dendrogram. Hasil analisis gerombol menggunakan skor dari 8 lokus dari ketiga marka ditunjukkan pada Gambar 4. Hasil analisis menunjukkan adanya dua kelas yang membedakan kelas toleran dan kelas peka.

Marka molekuler yang dapat digunakan untuk mengkonfirmasi adalah marka yang memiliki asosiasi dengan karakter fenotipik terutama yang menandakan sifat toleran. Uji t digunakan untuk membandingkan rata-rata nilai fenotipe dari kelompok genotipe dengan skor marka molekuler 0 (tanpa pita) dibandingkan dengan kelompok dengan skor 1 (ada pita). Jika berdasarkan uji t terdapat perbedaan antar kelompok, maka dapat dikatakan bahwa marka tersebut berasosiasi atau terkait dengan karakter fenotipik tertentu. Yohana et al. (2018) menganggap adanya sebuah quantitative trait loci (QTL) jika terdapat perbedaan nyata dalam rata-rata skor fenotipe untuk masing-masing kelompok. Hasil uji $\mathrm{t}$ yang berbeda nyata pada suatu karakter menunjukkan bahwa terdapat perbedaan antara rata-rata nilai suatu karakter terhadap polimorfisme marka (Tabel 1).

Berdasarkan uji t, diketahui bahwa marka RM228 pada semua alel diduga memiliki asosiasi dengan karakter skor menggulung dan panjang malai. Marka RM228 diduga memiliki asosiasi pula dengan karakter tinggi tanaman dan umur berbunga alel 200 bp. Marka RM328 pada alel 100 bp diduga bersosiasi dengan panjang malai, pada alel 200 bp diduga berasosiasi dengan jumlah anakan, dan pada 500 bp diduga berasosiasi dengan karakter gabah isi dan produktivitas (Tabel 1). Zhao et al. (2008) menyatakan bahwa RM228 yang berada di kromosom 10 merupakan QTL terkait dengan karakter laju fotosintetis daun bendera, frekuensi stomata, dan bobot daun spesifik dan terdeteksi pula terkait dengan bobot hasil pada turunan Asominori/IR24 CSSL, JYQ8/JX17 DH, Nipponbare/Kasalath BIL, Nipponbare/ Kasalath BIL and 254 Teqing ILs. Menurut Lang dan Buu (2008), RM328 berada di kromosom 9 dan diduga terkait erat dengan toleransi kekeringan. Beragamnya karakter fenotipik yang berasosiasi dengan satu marka molekuler diduga karena adanya efek gen pleiotropi. Ookawa et al. 


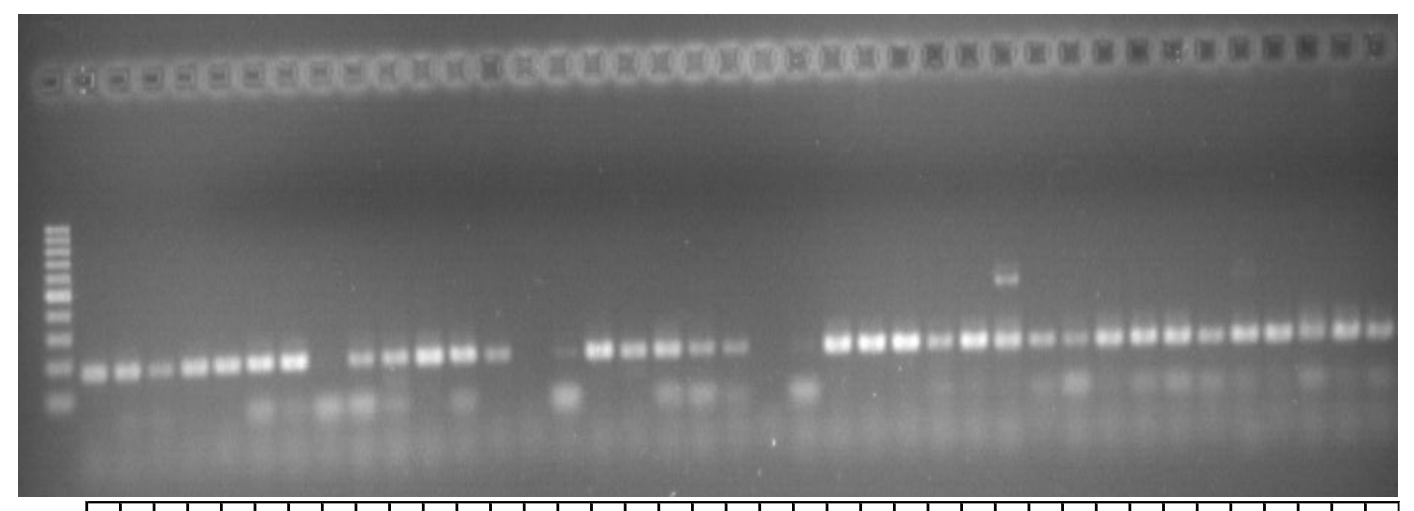

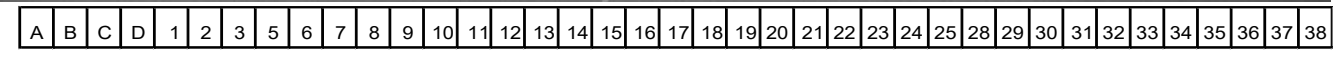

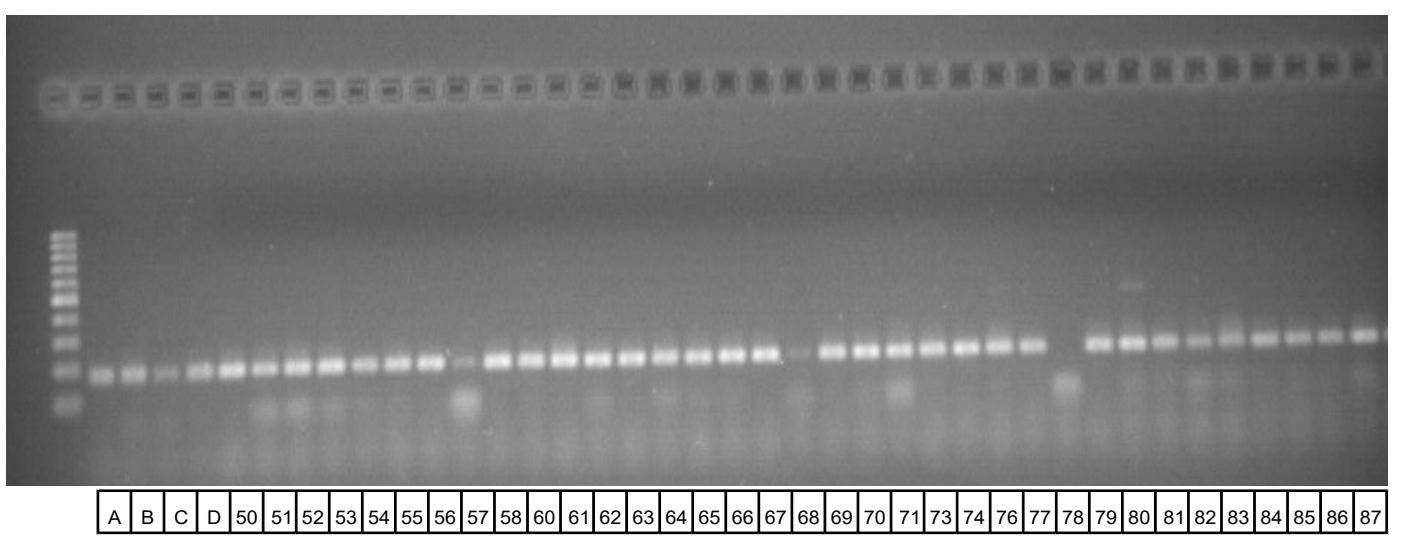

Keterangan: A = Inpari 30 Ciherang Sub1; B = IR42; C = Limboto; D = IR20; Angka 1, 2, 3, dan seterusnya menyatakan nomor galur; Ladder $1,000 \mathrm{bp}$

Gambar 3. Visualisasi RM328 pada analisis molekuler galur-galur padi

(2010) melaporkan bahwa QTL SCM2 yang berperan dalam kekuatan batang, terkait pula dengan karakter pembentukan stuktur malai sebagai efek dari gen pleiotropi.

Dari 96 genotipe yang digunakan dalam analisis molekuler, hanya 83 genotipe yang secara keseluruhan memunculkan band pada seluruh marka yang digunakan. Hasil analisis gerombol menggunakan software PBSTAT berdasarkan 3 marka (RM228, RM248, dan RM328) membagi 83 genotipe menjadi 2 kelas (Gambar 4). Selanjutnya hasil uji t menunjukkan bahwa pada karakter

Tabel 1. Hasil uji t rata-rata nilai fenotipik pada tiap pita analisa molekuler galur-galur padi

\begin{tabular}{|c|c|c|c|c|c|c|}
\hline \multirow{2}{*}{ Marka } & \multirow{2}{*}{$\mathrm{bp}$} & \multirow{2}{*}{ Karakter } & \multicolumn{2}{|c|}{ Rata-rata nilai fenotipe } & \multirow{2}{*}{ Selisih } & \multirow{2}{*}{ p-value } \\
\hline & & & 0 & 1 & & \\
\hline \multirow[t]{8}{*}{ RM228 } & 100 & Skor menggulung & 6.38 & 4.79 & $1.59 *$ & 0.024 \\
\hline & & Panjang malai (cm) & 22.84 & 24.30 & $-1.46 * *$ & 0.008 \\
\hline & 150 & Skor menggulung & 4.74 & 6.57 & $-1.83 * *$ & 0.005 \\
\hline & & Panjang malai $(\mathrm{cm})$ & 24.25 & 22.99 & $1.26^{*}$ & 0.030 \\
\hline & 200 & Skor menggulung & 4.94 & 6.80 & $-1.86^{*}$ & 0.011 \\
\hline & & Tinggi tanaman $(\mathrm{cm})$ & 84.40 & 76.20 & $8.20 *$ & 0.047 \\
\hline & & Umur berbunga (hari) & 88.94 & 86.85 & $2.09 *$ & 0.034 \\
\hline & & Panjang malai (cm) & 24.15 & 22.51 & $1.64 *$ & 0.015 \\
\hline \multirow[t]{4}{*}{ RM328 } & 100 & Panjang malai (cm) & 23.51 & 24.65 & $-1.14^{*}$ & 0.043 \\
\hline & 200 & Jumlah anakan & 11.04 & 8.22 & $2.82 *$ & 0.044 \\
\hline & 500 & Jumlah gabah isi per malai (butir) & 70.60 & 58.58 & $12.02 * *$ & 0.000 \\
\hline & & Produktivitas (ton ha-1) & 1.48 & 0.21 & $1.27 * *$ & 0.000 \\
\hline
\end{tabular}

Keterangan: $0=$ tidak ada pita; $1=$ ada pita $*=$ nyata pada taraf $5 \%$; * = nyata pada $\operatorname{taraf} 1 \%$ 


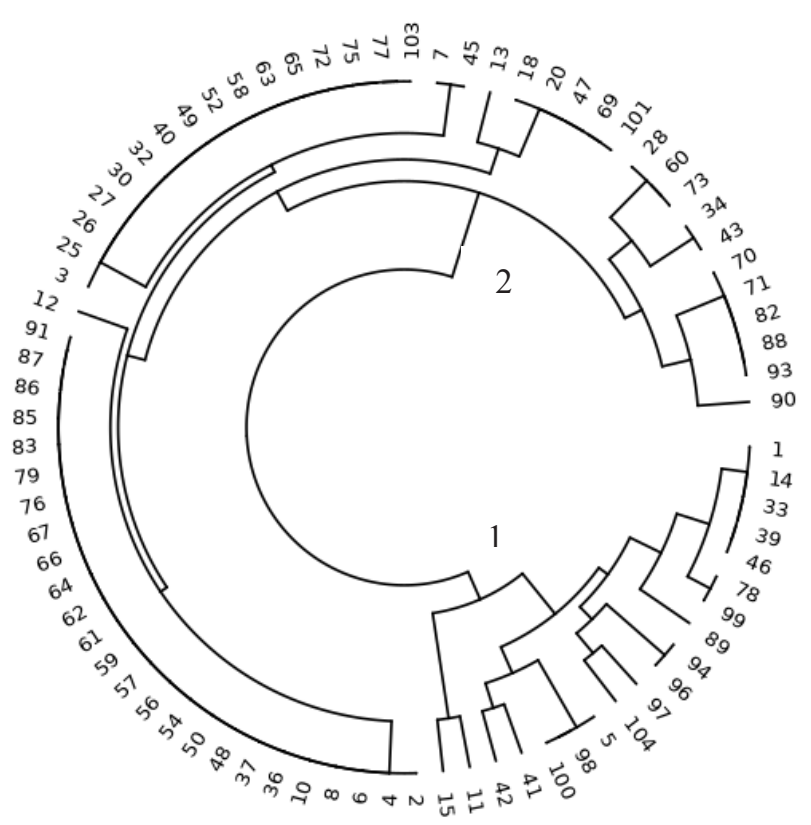

Keterangan: Kelompok $1=$ tidak toleran; kelompok $2=$ toleran Gambar 4. Dendogram galur-galur padi yang diuji menggunakan marka molekuler

skor menggulung dan panjang malai menunjukkan adanya perbedaan yang nyata antara kelompok 1 dan 2 (Tabel 2). Hal tersebut menunjukkan bahwa delapan alel pada tiga marka tersebut diduga dapat dimanfaatkan sebagai marka seleksi untuk karakter toleran kekeringan. Namun masih diperlukan penelitian lebih lanjut, diantaranya adalah penelitian genetic dan association mapping. Hal ini diperlukan untuk mengidentifikasi asosiasi marka dengan karakter toleran kekeringan dan beberapa karakter fenotipik lainnya.

Melihat adanya indikasi asosiasi antar marka molekuler dengan karakter fenotipik, maka hasil analisis molekuler dapat menguatkan hasil skrining toleransi kekeringan secara fenotipik. Penelitian ini bertujuan untuk mengkonfirmasi toleransi kekeringan yang sebelumnya telah dilakukan secara fenotipik pada penelitian Wening et al. (2019). Dari sepuluh galur yang terindikasi toleran terhadap cekaman kekeringan fase generatif berdasarkan skrining secara artifisial (Wening et al., 2019), terdapat tujuh galur yang terkonfirmasi secara molekuler yaitu yang berada dalam satu kelompok dengan varietas pembanding toleran Limboto

Tabel 2. Hasil uji t rata-rata nilai fenotipik antara kelas 1 dan 2 hasil analisis clustergram pada penelitian konfirmasi toleransi kekeringan galur-galur padi

Kelompok Skor menggulung Panjang malai $(\mathrm{cm})$

\begin{tabular}{lll}
\hline Kelompok 1 & 6.69 & 22.77 \\
\hline Kelompok 2 & 4.73 & 24.29 \\
Nilai t & 3.19 & -2.90 \\
p-value & 0.004 & 0.007 \\
\hline
\end{tabular}

(no 103). Ketujuh galur tersebut ialah B13983E-KA-12-2, B13507E-MR-19, B14366E-KY-50, BP20452e-PWK-0SKI-1-1, BP20452e-PWK-0-SKI-2-4, BP20452e-PWK-0SKI-3-3, dan BP29790d-PWK-3-SKI-1-5. Ketujuh galur tersebut juga dinyatakan toleran kekeringan secara fenotipik (Wening et al., 2019).

\section{KESIMPULAN}

Berdasarkan analisis molekuler terdapat 7 galur toleran kekeringan yang terkonfirmasi berdasarkan marka RM228, RM248, dan RM328 berada satu group dengan cek toleran cekaman kekeringan. Ketujuh galur tersebut adalah B13983E-KA-12-2, B13507E-MR-19, B14366E-KY-50, BP20452e-PWK-0-SKI-1-1， BP20452e-PWK-0-SKI-2-4, BP20452e-PWK-0-SKI-3-3, dan BP29790d-PWK-3-SKI1-5. Marka RM228, RM248, dan RM328 diduga dapat dimanfaatkan sebagai marka seleksi, namun perlu dilakukan validasi melalui genetic dan association mapping.

\section{DAFTAR PUSKATA}

Afa, L.O., B.S. Purwoko, A. Junaedi, O. Haridjaja, I.S. Dewi. 2013. Deteksi dini toleransi padi hibrida terhadap kekeringan menggunakan PEG 6000. J. Agron. Indonesia 41:9-15.

Akbar, M.R., B.S. Purwoko, I.S. Dewi, W.B. Suwarno. 2018. Penentuan indeks seleksi toleransi kekeringan galur dihaploid padi sawah tadah hujan pada fase perkecambahan. J. Agron. Indonesia 46:133-139.

Anupam, A., J. Imam, S.M. Quatadah, A. Siddaiah, S. Prasad Das, M. Variar, P.N. Mandal. 2017. Genetic diversity analysis of rice germplasm in Tripura State of Northeast India using drought and blast linked markers. Rice Sci. 124:10-20.

Bahagiawati. 2011. Peran markah molekuler dalam pemuliaan tanaman. Badan Litbang Pertanian. Edisi 16-22 Maret 2011 No.3397. Jakarta, Indonesia.

Cahyadi, E., A. Ete, U. Made. 2013. Identifikasi karakter fisiologis dini padi gogo lokal Mangkawa terhadap cekaman kekeringan. Agrotekbis. 1:228-235.

Daniel, I.O., J.A. Adetumbi, O.O. Oyelakin, S.A. Olakojo, M.O. Ajala, S.O. Onagbesan. 2012. Application of SSR markers for genetic purity analysis of parental inbred lines and some commercial hybrid maize (Zea mays L.). Amer. J. Expt. Agric. 2:597-605.

Efendi, R., Y. Musa, M.F. Bdr, M.D. Rahim, M. Azrai, M. Pabendon. 2014. Seleksi jagung inbrida dengan marka molekuler dan toleransinya terhadap kekeringan dan nitrogen rendah. J. Pen. Pert. Tan. Pangan 20:43-53. 
Hipi, A., M. Surahman, S. Ilyas, Giyanto. 2012. Seed genetic purity assessment of hybrid maize using microsatellite markers (SSR). In Proceeding of an International Maize Conference. Gorontalo, 21-23 November 2012.

Kartina, N., B.S. Purwoko, I.S. Dewi, D. Wirnas, A. Nindita. 2019. Skrining awal toleransi galur-galur dihaploid padi gogo terhadap cekaman kekeringan pada stadia bibit. J. Agron. Indonesia 47:1-8.

Lang, N.T., B.C. Buu. 2008. Fine mapping for drought tolerance in rice (Oryza sativa L.). Omonrice. 16:915 .

Mulsanti, I.W., M. Surahman, S. Wahyuni, D.W. Utami. 2013. Identifikasi galur tetua padi hibrida dengan marka SSR spesifik dan pemanfaatannya dalam uji kemurnian benih. J. Pen. Pert. Tan. Pangan 32:1-8.

Nuraida, D. 2012. Pemuliaan tanaman cepat dan tepat melalui pendekatan marka molekuler. El-Hayah 2:97-103.

Ookawa, T., T. Hobo, M. Yano, K. Murata, T. Ando, H. Miura, K. Asano, Y. Ochiai, M. Ikeda, R. Nishitani, T. Ebitani, H. Ozaki, E.R. Angeles, T. Hirasawa, M. Matsuoka. 2010. New approach for rice improvement using a pleitropic QTL gene for lodging resistance and yield. Nature Comm. 1:132.

Selvi, G.S.A., S. Hittalmani, and G. Uday. 2015. Root QTL pyramiding through marker-assisted selection for enhanced grain yield under low moisture stress in rice (Oryza sativa L.). J. Rice Res. 4:1-5.

Semagn, K., Y. Beyene, D. Makumbi, S. Mugo, B.M. Prasanna, C. Magorokosho, G. Atlin. 2012. Quality control genotyping for assessment of genetic identity and purity in diverse tropical maize inbred lines. Theoret. Appl Genet. 125:1487-1501.

Sitaresmi, T., W.B. Suwarno, C. Gunarsih, Nafisah, Y. Nugraha, P. Sasmita, A.A. Daradjat. 2019.
Comprehensive stability analysis of rice genotypes through multi-location yield trials using PBSTATGE. Sabrao J. Breed. Genet. 51:355-372.

Tresniawati, C., N. Yuniyati, E. Randriani. 2014. Penggunaan marka molekuler dalam seleksi genotipe kakao dengan sifat kadar lemak tinggi. Bunga Rampai Inovasi Teknologi Bioindustri Kakao. 39-46.

Wening, R.H., B.S. Purwoko, W.B. Suwarno, I.A. Rumanti, N. Khumaida. 2019. Seleksi simultan karakter daun mengering dan produktivitas pada galur-galur padi. J. Agron. Indonesia 47:232-239.

Widyastuti, Y., B.S. Purwoko, M. Yunus. 2016. Identifikasi toleransi kekeringan tetua padi hibrida pada fase perkecambahan menggunakan polietilen glikol (PEG) 6000. J. Agron. Indonesia 44:235-241.

Yang, X., Y. Xu, T. Shah, H. Li, Z. Han, J. Li, J. Yan. 2011. Comparison of SSRs and SNPs in assessment of genetic relatedness in maize. Genetica 139:10451054.

Yohana, K. Adisyahputra, K.R. Trijatmiko. 2018. Validasi QTL dan aplikasinya untuk perbaikan sifat toleran keracunan Al pada padi. Bioma 4:37-48.

Yue, B.W. Xue, L. Xiong, X. Yu, L. Luo, K. Cui, D. Jin, Y. Xing, Q. Zhang. 2006. Genetic basis of drought resistance at reproductive stage in rice: separation of drought tolerance from drought avoidance. Genetics 172:1213-1228.

Yullianida, Suwarno, S.W. Ardhie, H. Aswidinnoor. 2014. Uji cepat toleransi tanaman padi terhadap cekaman rendaman pada fase vegetatif. J Agron. Indonesia 42:89-95.

Zhao, X., J. Xu, M. Zhao, R. Lafitte, L. Zhu, B. Fu, Y. Gao, Z. Li. 2008. QTLs affecting morphophysiological traits related to drought tolerance detected in overlapping introgression lines of rice (Oryza sativa L.). Plant Sci. 174:618-625. 